\title{
'N ONDERSOEK NA DIE PERSOONLIKHEIDSEIENSKAPPE VAN INBELSENTRUMKONSULTANTE
}

\author{
Y MOLLER \\ F CROUS \\ JM SCHEPERS \\ Departement Menslikehulpronbestuur \\ Randse Afrikaanse Universiteit
}

\begin{abstract}
An investigation into the personality traits of call centre consultants. Despite the fact that nearly all service organisations in South Africa use call centres to interact with clients, there is limited research detailing the factors that influence staff turnover. It was therefore decided to investigate the personality traits of call centre consultants who experience work satisfaction. This information could help organisations to maintain an effective approach in managing staff turnover. The Minnesota Satisfaction Questionnaire (MSQ) and Jackson Personality Research Form (PRF-E) were applied to a sample of 103 persons. The results showed that there was not a unique personality profile in respect of work satisfaction. However, a self-assertive personality type was identified that is dissatisfied with the extent of work variety in call centres.
\end{abstract}

\section{OPSOMMING}

Nieteenstaande die feit dat byna elke diensleweringsinstansie in Suid-Afrika van inbelsentrums gebruik maak om met kliënte sake te doen, bestaan daar min navorsing oor die aspekte wat 'n rol speel in personeelomset. Daar is derhalwe besluit om die persoonlikheidseienskappe van inbelsentrumkonsultante wat werksbevrediging ervaar te ondersoek. Dié inligting sal organisasies in staat stel om 'n effektiewe benadering ten opsigte van personeelomset te volg. Die Minnesota Satisfaction Questionnaire (MSQ) en die Jackson Personality Research Form (PRF-E) is op 'n steekproef van 103 persone toegepas. Die resultate toon dat daar nie 'n unieke persoonlikheidsprofiel geïdentifiseer kon word wat bepalend is van werksbevrediging nie. 'n Selfgeldende persoonlikheidstipe is wel geidentifiseer wat ontevrede is met die mate van werksverskeidenheid in inbelsentrums.

\section{SYNOPSIS}

World wide the call centre industry has shown remarkable growth of late. A spurt in technological development in the field of telecommunications and the integration of telephones and computers have given rise to this phenomenon. The telephonic call centre provides customers with an alternative to paying a personal visit to an organisation, and offers a one-stop service. It enables personal contact without the high costs of one-on-one interaction. The primary benefit any call centre holds for an organisation, is its cost-effectiveness.

The quality of a call centre's services depends on the skills of its employees. The call centre consultant should be knowledgeable about a wide range of technical, financial and law aspects, and has to be a skilled communicator. For many customers the call centre consultant represents the only direct contact with a representative of the organisation. As such the consultant has a profound influence on the customer's perception of the organisation.

Working conditions in call centres have not always been conducive to optimal consulting performance. Call centres have been labelled the "sweat shops" of the nineties, or the information era's "production line". Because of an increased emphasis on technology and formal (rigid) systems which are designed for effectiveness, the daily tasks of the call centre consultant have become standardised and highly controlled. Consequently consultants tend to experience their jobs as repetetive, lacking in challenge, limited in scope and having few prospects for development and enrichment. A high percentage of consultants reportedly experience their jobs as stressful. Those who experience their call centre work in a negative way may transfer their feelings (consciously or unconsciously) to the customer.

Given the particular demands of call centre conditions the following question arises: what type of person will experience work satisfaction in a call centre environment?

The aim of this study was to investigate the personality traits of call centre consultants who experience work satisfaction. Having

Versoeke vir afskrifte moet gerig word aan: F Crous, Departement

Menslikehulpbronbestuur, RAU, Posbus 524, Auckland Park, 2006 ascertained what personality traits are characteristic of satisfied call centre consultants, cutt-offs can be set on the appropriate tests for use in future selection of call centre consultants. This should lead to greater satisfaction of call centre consultants, and raise their contribution to the organisation as such. In order to meet the objectives of the study the following hypotheses were set and systematicaly tested:

Hypothesis 1: There are statistically significant differences in the means of call centre consultants that experience work satisfaction and those who do not, in respect of the various dimensions of the Jackson Personality Research Form.

Hypothesis 2: There are statistically significant correlations between the various dimensions of the Minnesota Satisfaction Questionnaire (MSQ) and the dimensions of the Jackson Personality Research Form (JPRF)

Hypohtesis 3: There are statistically signfiicant correlations between age, years of service at call centre, and total years of service, on the one hand, and the total score on the MSQ on the other hand.

To start off with the MSQ and JPRF were applied to 103 call centre consultants. Next, the 20 scales of the MSQ were subjected to a principal factor analysis. Only one factor emerged and was interpreted as general work satisfaction.

Similarly, the 22 scales of the JPRF were also subjected to a principal factor analysis, and yielded four factors. These factors were interpreted as self-assertion, dependence on people, impulsivity, and a search for knowledge. The reliabilities of the corresponding scales were 0,$853 ; 0,756 ; 0,649$ and 0,734 respectively.

A median cut was made on the total score of the MSQ and two contrasting groups were formed, viz those low in work satisfaction and those high in work satisfaction. Accordingly the two groups were compared in respect of the four scales of the JPRF. None of the scales yielded significant differences. Hypothesis 1 was therefore rejected.

Next the scores of the JPRF were correlated with the 20 scores of the MSQ. Only one statistically significant correlation was found, namely 
between self-assertion and variety of work. This correlation was negative $(r=0,199, p=0,043)$. Self-assertive call centre consultants are therefore unhappy with the lack of variety in their work.

Thus there is only partial support for Hypothesis 2.

There was a positive correlation between age and years of service at call centre $(r=0,383, p<0,001)$. However, age correlated negatively with general work satisfaction $(r=-0,217, p=0,028)$. Total number of years service also correlated negatively with general work satisfaction $(r=-0,246, p=0,0122)$.

The implications of the findings are discussed.

Inbelsentrums is ' $n$ relatief nuwe diensleweringskanaalontwikkeling (Rademeyer, 1997, p. 1). Die posbenaming "Inbelsentrumbestuurder" was selfs in 1995 nog ongekend (Walkden, 1998, p. 3). Tans het die inbelsentrum-industrie egter 'n jaarlikse groeikoers van $20 \%$ in sommige ontwikkelde lande en word bestempel as die werkterrein wat oral ter wêreld die vinnigste groei (Walkden, 1998, p. 3). Voorspellings dui daarop dat die aantal mense wat in inbelsentrums werk, wêreldwyd sal styg van 530000 in 1996 tot 8,9 miljoen in 2002 (Bidoli, 1997, p. 65). Ook in Suid-Afrika het bykans elke diensleweringsorganisasie, onder meer banke en versekeringsinstansies, deesdae so 'n hulpsentrum. Die ontploffing in dié industrie is hoofsaaklik toe te skryf aan die golf van tegnologiese vooruitgang in telekommunikasie en die integrasie van die telefoon en rekenaar.

\section{Wat is ' $n$ inbelsentrum?}

Volgens Rademeyer $(1997$, p. 7) is 'n inbelsentrum 'n plek waar 'n groep mense van so min as drie telefonies sake bedryf. Dié groep mense verskaf 'n eenstop-"winkel" of kontakpunt vir kliëntediens, verkope en produk-informasie. Dit word verder omskryf as ' $n$ bedryf wat gevorderde tegnologie integreer met 'n effektief ontwerpte besigheidsproses en menslike hulpbronne van 'n hoë kaliber. Tegnologie stel werknemers deesdae in staat om uitnemende diens aan kliënte te lewer. Inbelsentrums word gebruik in organisasies wat hoëvolume- en gereelde kliëntekontak noodsaak (Rademeyer, 1997, p. 8). Die telefoniese inbelsentrum bied aan kliënte ' $n$ alternatief tot ' $n$ persoonlike besoek aan die organisasie.

Om toegang tot ' $\mathrm{n}$ inbelsentrum te verkry, gebruik organisasies 'n "enkele telefoonnommer"-konsep, wat meestal 'n nommer is met dieselfde koste as 'n plaaslike oproep. Die telefoniese interaksie kan na of van die kliënte wees - vandaar die terme "uitgaande" en "inkomende" inbelsentrum (Rademeyer, 1997, p. 10). ' $n$ Tipiese inbelsentrum kan enige iets van tien tot 300 konsultante hê, wat verdeel is in groepe of spanne. 'n Oproepbestuurstelsel monitor konsultante se aktiwiteite en verskaf aan die spanleier of bestuurder informasie om die gekwantifiseerde produktiwiteit van die inbelsentrum en konsultante te bepaal. Die oproep-bestuurstelsel word verder gebruik om konsultante se oproepe te evalueer, ten einde te verseker dat die informasie wat aan kliënte verskaf word, aan die nodige kwaliteitstandaarde voldoen (Walkden, 1998, p. 3). Tans is die klem steeds meer op die toename in kwantiteit as in kwaliteitsverbetering, maar dit word geleidelik aanvaar dat 'n mededingende voordeel slegs behaal kan word deur toenemend te fokus op die kwaliteit van die informasie wat verskaf word. Skedulering van konsultante se tyd berus op ontleding van besige tye in die inbelsentrum. As sodanig is ' $n$ werksessie hoogs gekontroleerd en besig.

\section{Voordele van inbelsentrums}

Die besigheidsrasionaal vir die vestiging van inbelsentrums is gebaseer op die moontlikheid van 'n enkele kontakpunt vir kliënte. Volgens Rucker (2001, p. 1) stel inbelsentrums organisasies in staat om geografies verspreide markte op 'n kosteeffektiewe manier te bereik. Om besigheid honderde kilometer ver te doen, word eenvoudiger wanneer kliënte van mening is dat die organisasie slegs met 'n enkele oproep bereik kan word.
Rademeyer (1997, p. 25) is van mening dat die enkele kontakpunt verdere voordele inhou soos verhoogde kliëntebevrediging en lojaliteit en die vestiging van 'n informasiedatabasis van kliënte. ' $n$ Databasis is ' $n$ waardevolle bron vir die organisasie, wat deur ontleding gebruik kan word om op 'n meer persoonlike vlak diens te verskaf en toe te spits op die unieke behoeftes van individuele kliënte. Sekere data kan byvoorbeeld die organisasie se winsgewendste kliënte aandui, wat die kliënt se waarde is binne ' $n$ bepaalde tydsduur, en watter tipe kliënte geneig is om hul lidmaatskap op te skort. Beresford $(1999$, p. 20) is van mening dat die grootste voordeel van die inbelsentrum die persoonlike kontak is met die kliënte, maar sonder die gepaardgaande koste van een-tot-een interaksie.

Die beste stelsels, prosesse en tegnologie sal beperk wees sonder toegewyde, bevoegde konsultante wat die telefone beantwoord (Rademeyer, 1997, p. 17). Beresford $(1999$, p. 20) sê in hierdie verband dat werk in inbelsentrums veeleisend is en bekwame werknemers derhalwe nodig is. Daar sal van enige iemand wat in die inbelsentrum van 'n groot finansiële instelling werk, verwag word om 'n kenner te wees van ' $n$ wye reeks tegniese, finansiële en regsaspekte en ook om oor goeie kommunikasievaardighede te beskik. Daarbenewens sal sommige inbelsentrums nie ' $n$ persoon sonder ' $n$ akademiese graad wat verwant is aan die industrie van die inbelsentrum, aanstel nie (O'Brien, 2000, p. 1). Die tyd, tot 'n paar jaar gelede, is verby dat matrikulante in inbelsentrums werk bloot omdat hulle geen ander werk kon kry nie.

\section{Probleme in inbelsentrums}

Die inbelsentrumindustrie het al verskeie kere onder die kruisvuur gekom en word soms na verwys as die "sweetfabriek" van die negentigerjare (Walkden, 1999 p. 4) en die inligtingsera se "produksielyn". In Call Centre Staff More Likely to be Stressed $(2000$, p. 1) is bevind dat die eentonige aard van die werk en min selfbeheer wat die konsultante het oor hul werk, tot stres aanleiding gee. Dit hou implikasies vir die organisasie in omdat inbelsentrumkonsultante die organisasie se eerste interaksie met kliënte is en as sodanig kliënte se persepsie van die organisasie beïnvloed (Beresford, 1999, p. 20). Vir talle kliënte is die enigste kontak met die organisasie deur die inbelsentrum en hoewel interaksie meestal slegs ' $n$ paar minute duur, is dit die enigste basis waarop die kliënt 'n persepsie van die organisasie kan vorm (Harper, 2001, p. 2).

'n Oordrewe klem op tegnologie en formele stelsels wat ontwerp is om effektiwiteit te bevorder, het tot gevolg gehad dat inbelsentrumkonsultante se take grootliks gestandaardiseer is. Dit het egter ook daartoe gelei dat konsultante gekluister is aan teks op 'n rekenaarskerm wat oor en oor herhaal moet word onder streng beheer, ten einde kwaliteit en hoë produksie af te dwing. Hierdie take lei volgens Walkden (1998 p. 4) tot verveling en eentonigheid. Die probleem kom veral voor by inbelsentrums waar inkomende oproepe gehanteer en konsultante gekonfronteer word met die beantwoording van oproepe wat mekaar vinnig opvolg en die herhaling van eentonige informasie. Indien die konsultant dit beleef dat die stelsel sy/haar vaardighede nie voldoende benut nie, kan dit lei tot ' $n$ verlies aan werksbetekenis, motivering en waardebesef en 'n gebrek aan selfagting. Die engheid en herhalende aard van die konsultant se dagtaak mag daarbenewens tot vervreemding lei (Walkden, 1998, p. 4).

Walkden (1998 p. 5) merk op dat daar min ruimte is vir loopbaanontwikkeling in die inbelsentrum. Vanweë die plat struktuur en breë spanwydte wat in 'n inbelsentrum bestaan, het konsultante beperkte geleenthede vir bevordering. Daar is tientalle inbelsentrumkonsultante, met spanleiers wat oor 'n relatief groot groep konsultante toesig hou en oorhoofs bestuur word deur bestuurders. Hoewel 'n konsultant 'n loopbaan vir homself in die inbelsentrum kan beplan, is die realiteit dat slegs 'n paar verder sal vorder as telefoonoperateurs. 
Benewens die belewing van hoë stresvlakke is daar 'n besorgdheid oor die fisieke probleme wat veroorsaak word deur die langdurige gebruik van die tegnologie. Konsultante kla soms oor hoofpyn en oogprobleme, wat tot verdere stres aanleiding gee (Walkden, 1998, p. 5).

Vanweë bogenoemde redes word werk in ' $n$ inbelsentrum nie altyd as positief ervaar nie en 'n gevolg daarvan is besonder hoë personeelomset. Hoë personeelomset word bestempel as die grootste uitdaging waarmee die bestuur van inbelsentrums gekonfronteer word (Walkden, 1998 p. 5). Daar word beraam dat personeelomset in inbelsentrums in die Verenigde Koninkryk nagenoeg $30 \%$ is. ' $n$ Onlangse opname oor personeelomset wat in 186 Amerikaanse inbelsentrums gedoen is, het getoon dat die gemiddelde indiensnemingstydperk vir inbelsentrumkonsultante twee jaar is (Agent Staffing and Retention Study, p. 2). Hierdie kort tydperk het ' $n$ besliste finansiële impak op die organisasie indien die sleutelfaktore in ag geneem word wat 'n rol speel by die vervanging van 'n konsultant, naamlik:

- Verlatingskoste (administrasie van die salaris van die konsultant wat die inbelsentrum verlaat)

- Vervangingskoste (werwing, tyd van onderhoude, plasingskoste)

- Oorgangskoste (opleidingskoste, onproduktiewe tye waartydens die nuweling nog touwys gemaak word, oriëntering)

- Indirekte koste (verlies van kliëntediens en -bevrediging).

Walkden (1998 p. 8) het bereken dat 'n personeelomsetverbetering van nege tot agtien maande in ' $n$ inbelsentrum met 100 konsultante ' $n$ kostebesparing van $£ 270000$ (sowat R3 780 000) per jaar beteken, of die jaarlikse salarisse van 22 konsultante.

Walkden (1998, p. 9) het in onderhoude met inbelsentrumkonsultante die volgende probleme geïdentifiseer wat aanleiding gee tot hoë personeelomset: vervelige en herhalende werk, lae werknemermoraal, tegnologiese dissonansie, beperkte bevorderingsgeleenthede, stres en 'n gebrek aan prestasie. Die konsultant wat sy werk in die inbelsentrum negatief beleef, kan sy/haar negatiewe gevoelens bewustelik of onbewustelik aan kliënte oordra (Beresford, 1999, p. 20).

Die belangrikheid van keuring van die regte tipe konsultante Die eise wat inbelsentrums stel, laat die vraag ontstaan watter tipe persoon in dié werksomgewing aard. Hierdie vraag hou met keuring verband. Hakstian en Scratchley $(1999$, p. 1) is van mening dat organisasies wat sistematiese voorafindiensnemingsprosedures gebruik, 'n stewige grondslag lê vir 'n hoëpresterende werkmag in die inbelsentrum, teen 'n fraksie van die koste van toekomstige opleidingsintervensies. Die skrywers stel verder dat inbelsentrumbestuurders geneig is om toetsing by die keuringsfase gering te skat. Die gevolg is dat hulle die organisasie skade berokken. Onvoldoende keuring van applikante lei tot swak kliëntediens, wat bedryfskostes kan laat verhoog en kliënte wegdryf.

Navorsing wat deur Hakstian en Scratchley $(1999$, p. 2) gedoen is oor die beste manier om inbelsentrumapplikante te beoordeel, lig sekere aspekte uit waaraan 'n goeie keuringstoets moet voldoen:

- Die keuringstelsel moet gebaseer wees op objektiewe, toegespitste navorsing. Gepubliseerde navorsing in wetenskaplike vaktydskrifte is ' $\mathrm{n}$ goeie bron van tipes stelsels wat op ' $n$ wetenskaplike wyse ondersoek is. Betroubaarheid en geldigheid word hier uitgesonder as twee kernpilare wat regverdigheid, akkuraatheid, bruikbaarheid en wetlike verdedigbaarheid van die keuringsproses behels.

- Die beoordelingstelsel moet omvattend wees. Geen geïsoleerde toets kan 'n effektiewe vooruitskatting maak van inbelsentrumkonsultante se prestasie nie, maar 'n goed nagevorsde stel metinge kan wel.

- Die beoordelingstoets moet die korrekte dimensies meet. In hul studie is bevind dat die volgende persoonlikheids- eienskappe noodsaaklik is vir inbelsentrumkonsultante se effektiwiteit: toleransie en vertroue, kreatiewe denke en vindingrykheid, nie-ekstreme konvensionele waardes, selfbeheer, 'n afwesigheid van sinisme, pligsgetrouheid en 'n gevoel van welsyn. Hollman (2001, p. 1) beskou 'n positiewe uitkyk en deursettingsvermoë as belangrik vir die rol, asook dat konsultante kalmte moet behou indien hulle met ontstoke kliënte werk.

Daar moet dus van keuringstoetse gebruik gemaak word wat op die kritiese eienskappe van die pos konsentreer en nie eienskappe wat daarvoor irrelevant is nie.

Vroeër is daarop gewys dat hoë personeelomset tans een van die grootste uitdagings vir inbelsentrumbestuur is. Benewens kritiese persoonlikheidseienskappe wat die inbelsentrumkonsultant moet besit om effektief te wees in sy/haar rol, is dit ook nodig vir bestuur om die persoonlikheidseienskappe te identifiseer wat onderliggend is aan die tydperk waarin 'n konsultant werksaam is in die inbelsentrum.

Porter en Steers toon in een van hul studies 'n verband aan tussen werksbevrediging en personeelomset (Gruneberg, 1979, p. 113): hoë werksbevrediging gee aanleiding tot laer vlakke van personeelomset en lae werksbevrediging lei tot hoër vlakke. Indien die persoonlikheidseienskappe van konsultante wat werksbevrediging ervaar bepaal kan word, kan keuringstoetse gebruik word wat op dié eienskappe konsentreer, ten einde die finansiële impak van hoë personeelomset teen te werk.

\section{Werksbevrediging}

Werksbevrediging is een van die onderwerpe wat die meeste in die sielkunde nagevors is (Gruneberg, 1979, p. 1). Die rede vir die populariteit van die onderwerp is duidelik - die meeste individue bring 'n groot deel van hul lewe by die werk deur. 'n Begrip vir die faktore onderliggend aan werksbevrediging relevant tot die verbetering van die welstand van individue, is derhalwe van belang. Indien in ag geneem word dat die volwassene die grootste deel van sy/haar lewe by die werk deurbring, is die belangrikheid van die keuse van 'n bevredigende werkomgewing baie duidelik (Lew, 1997, p. 1). Dit is daarom belangrik om te verstaan onder watter omstandighede 'n individu die geskikste sal wees vir sy/haar werkomgewing asook die essensie van wat nodig is vir 'n persoon om gelukkig en tevrede te wees in sy/haar werk.

\section{Wat is werksbevrediging?}

Werksbevrediging is ' $\mathrm{n}$ emosionele toestand wat voorkom as 'n individu sy/haar werk beoordeel en bepaal dat dit aan sy/haar spesifieke werkswaardes voldoen (Lew, 1997, p. 11)

Teorieë oor werksbevrediging word in twee kategorieë ingedeel, naamlik inhoudsteorieë en proses-teorieë (Gruneberg, 1979, p. 9). Onder inhoudsteorieë word Maslow se behoeftehiërargie en Herzberg se tweefaktor-teorie kortliks bespreek, aangesien veral dié teorieë relevant is vir die metingsinstrument wat gebruik sal word om werksbevrediging te bepaal en wat later bespreek sal word.

Een van die eerste behoefte teorieë is dié van Maslow, wat 'n behoeftehiërargie postuleer en behoeftes verdeel in laerordeen hoërorde-behoeftes (Gruneberg, 1979, p. 10). Die behoeftes is fisiologiese behoeftes, sekuriteitsbehoeftes, sosiale behoeftes selfagtingbehoeftes en selfaktualiseringsbehoeftes. Die eerste drie is laerorde-behoeftes en die laaste twee is hoërordebehoeftes. Maslow redeneer dat 'n persoon eers sal fokus op die hoërorde-behoeftes nadat die laerorde-behoeftes bevredig is. In Gruneberg (1979, p. 10) wys Locke op sekere beperkinge van Maslow se teorie. Locke is van mening dat daar geen bewyse vir die hiërargie van behoeftes bestaan nie. Hy sê ook dat daar altyd fisiese behoeftes sal wees wat bevredig moet word, al beweeg 'n persoon verder op in die hiërargie van 
behoeftes. Ondanks Locke se voorbehoud, is daar wel bewyse dat Maslow se teorie bevindinge op beroepsvlak en werksbevrediging kan verklaar.

Verwant aan Maslow se behoeftehiërargieteorie, is Herzberg se bekende tweefaktor-teorie van werksbevrediging (Gruneberg, 1979, p. 11). Herzberg onderskei tussen twee kategorieë faktore onderliggend aan werksbevrediging. Die eerste groep, genoem motiveerders, is faktore wat, indien dit teenwoordig is, aanleiding sal gee tot bevrediging, maar in die afwesigheid van dié faktore, nie daartoe sal lei dat die werkervaring onbevredigend is nie. Sulke faktore sluit in prestasie, erkenning en die intrinsieke belangstelling in die werk self en stem ooreen met Maslow se hoërorde-vlakke van selfagting en selfaktualisering. Die tweede groep word die higiënefaktore genoem en indien dit onvoldoende is, lei dit tot 'n onbevredigende werkervaring, maar indien voldoende, lei dit nie noodwendig tot werksbevrediging nie. Voorbeelde van die higiënefaktore is salaris, sekuriteit en fisiese werkomstandighede, wat ooreenstem met Maslow se laerorde-behoeftes. Deur die faktore in dié twee groepe te verdeel, redeneer Herzberg dat die oorsake van werksbevrediging en 'n onbevredigende werkervaring van mekaar verskil. Die kern van Herzberg se redenasie is dat faktore soos salaris, toesighouding en werkomstandighede inhoudsfaktore is en min te make het met die bereiking van werksbevrediging. Dit is noodsaaklike faktore, maar lei nie tot werksbevrediging nie. Hoewel daar kritiek teen verskeie aspekte van Herzberg se teorie is, is daar geen twyfel nie dat sy klem op die belangrikheid van motiveerders eerder as higiënefaktore as bydraend tot werksbevrediging, geregverdig is met wye aanvaarding (Gruneberg, 1979, p. 18).

Nieteenstaande die kritiek teen sowel Maslow as Herzberg, is albei teorieë bruikbaar in die praktyk. Dit herinner daaraan dat mense steeds mense bly as hulle werk toe gaan; dat mense nodig het om genot en trots in hul werk te ervaar; en dat hulle dit benodig saam met, en nie in die plek van regverdige salarisse en goeie werksomstandighede nie (Howarth, 1984, p. 16). Daar is op albei hierdie teorieë voortgebou en die verskillende gelysde kategorieë kom voor in die toets wat gebruik sal word om werksbevrediging te meet.

\section{Ander verwantskappe met werksbevrediging}

Daar is reeds bewys gelewer van 'n verband tussen werksbevrediging en personeelomset. 'n Ander verband wat kortliks bespreek sal word, is dié van werksbevrediging en werkbetrokkenheid. Lew (1997, p. 12) definieer werkbetrokkenheid as 'n spesifieke kognitiewe oortuigingstoestand vanweë 'n mens se identifikasie sy/haar werk. Dit verwys verder na 'n persoon se houding teenoor sy/haar werk en die sielkundige nabyheid wat 'n individu ervaar teenoor sy/haar huidige werk. Dit word onderskei van werksbevrediging, omdat laasgenoemde verwys na 'n emosionele toestand, terwyl werkbetrokkenheid 'n kognitiewe of oortuigingstoestand is. Gruneberg kom tot die gevolgtrekking dat werkbetrokkenheid 'n noodsaaklike vereiste vir werksbevrediging is, maar dit nie kan waarborg nie (Lew, 1997, p. 8). 'n Individu kan betrokkenheid teenoor sy/haar werk ervaar, maar sonder bevrediging. Die vlak van werkbetrokkenheid is egter ' $n$ aanduiding van die vlak van werksbevrediging of ' $n$ onbevredigende werkervaring. Kanungo bevind dat werkbetrokkenheid werksbevrediging veroorsaak, asook positiewe inspanning en prestasie, wat laer vlakke van personeelomset en afwesigheid tot gevolg het (Lew, 1997, p. 124).

Kanungo beweer dat betrokkenheid en vervreemding teenoorgestelde pole is van dieselfde sielkundige dimensie (Lew, 1997, p. 125). Indien werkbetrokkenheid gesien word as een pool op die enkele kontinuum van betrokkenheidvervreemding, kan werkvervreemding gedefinieer word as die toestand van sielkundige skeiding van werk. Roodt, Bester en Boshoff (Lew, 1997, p. 155) ondersteun dié bipolêre konseptualisasie van werkbetrokkenheid. Die resultaat van hul studie bewys dat individue met lae vlakke van werkbetrokkenheid meer werkvervreemding ervaar as dié met gemiddelde of hoë vlakke daarvan. Kanungo (1982, p. 89) noem vyf dimensies van vervreemding, naamlik magteloosheid, betekenloosheid, normloosheid, isolasie en selfverwydering. Indien 'n persoon volgens Blauner (1964, p. 16) magteloosheid ervaar as deel van vervreemding, reageer hy/sy slegs op 'n situasie, eerder as om proaktief op te tree. Die teenoorgestelde van magteloosheid is vryheid en beheer en behels vryheid oor die mate van fisiese beweging, byvoorbeeld om nie gekluister te wees aan die masjienproses nie, maar om die vermoë te hê om hom/haar daarvan te verwyder. Die teenpool van die werkvervreemde persoon is die persoon wat beheer het oor die tempo van sy/haar werk (Blauner, 1964, p. 20). Die dimensie van magteloosheid by werkvervreemding herinner sterk aan die rol van die inbelsentrumkonsultant. Op dieselfde manier kan die ander dimensies van vervreemding met mekaar in verband gebring word, wat gelyk is aan lae werkbetrokkenheid en inbelsentrumkonsultante se lae vlakke van werksbevrediging.

Volgens Gruneberg $(1979$, p. 53) het verskeie studies bewys dat poste wat lae vaardigheidsvlakke vereis en min verskeidenheid en outonomie bied, minder bevredigend is as poste wat ruimte laat vir individue om hul vermoëns uit te leef. Agho, Price \& Mueller (1992, p. 185) beweer dat outonomie 'n positiewe impak het op werksbevrediging, terwyl roetine 'n negatiewe impak het. Poste wat geen taak-identiteit ('n duidelike begin, middel en einde) het nie, het vir die meeste individue min betekenis. Die bewyse is oorweldigend dat sulke poste minder werksbevrediging bied as dié poste wat geleentheid gee vir groei en ontwikkeling. Een rede hoekom die toepassing van vaardighede so belangrik is vir werksbevrediging, is dat dit die individu ' $n$ mate van vryheid en verantwoordelikheid toelaat in sy/haar posisie (Gruneberg, 1979, p. 53).

Kongruensie tussen persoonlikheid en die werksomgewing is volgens Holland die bepalende faktor vir werksbevrediging (Nel, 1999, p. 48). Navorsing om werksbevrediging en persoonlikheid in pas te bring, kan in dié verband van nut wees, eerstens vir 'n organisasie om te weet watter inbelsentrumkonsultante werksbevrediging ervaar en tweedens om proaktief op te tree deur voornemende konsultante te werf wat 'n groter waarskynlikheid sal hê om werksbevrediging in 'n inbelsentrum te ervaar.

\section{Persoonlikheid}

Die Verklarende Sielkundewoordeboek definieër persoonlikheid as die geïntegreerde en dinamiese organisasie van 'n individu se psigiese, sosiale, morele en fisiese eienskappe, soos dit in sy/haar wisselwerking met die omgewing en ander persone tot uiting kom (Plug, Louw, Gouws en Meyer, 1997, p. 279). In die sielkunde verwys die term "eienskappe" meestal na die psigiese kwaliteite, dit wil sê die trekke van die persoonlikheid wat nie, soos die fisiese eienskappe, direk waargeneem kan word nie. Psigiese eienskappe is neigings of disposisies van persone om in sekere situasies op sekere wyses op te tree. Eienskappe word aan persone toegeskryf op grond van waarnemings in verskeie situasies waar hulle soortgelyke gedragswyses konsekwent openbaar het, of op grond van sielkundige toetse (Plug et al., 1997, p. 82).

Holland se teorie beskryf die interaksie tussen persoonlikheid en die omgewing (Lew, 1997, p. 2). Persoon-omgewingkorrelasie is een van die hoofaannames van Holland se teorie en is ook bestudeer in terme van werksbevrediging. Navorsingsresultate bevestig die verhouding tussen persoon-omgewingkorrelasie en werksbevrediging. Sowel Holland se teorie en dié van Lofquist en Dawis gaan van die veronderstelling uit dat indien 'n persoon se vermoëns, belangstellings en persoonlikheidseienskappe by die vereistes en interpersoonlike verhoudings van 'n werksomgewing pas, bevrediging verkry en sukses bereik sal word (Lew, 1997, p. 3). Williams $(2000$, p. 3) wys op die belangrikheid van noukeurige identifisering van die vereiste bevoegdhede van die inbelsentrumkonsultant - nie net kennis en vaardighede nie, maar ook dieper bevoegdhede stukrag verleen aan kennis en vaardighede, soos houdings, persoonlikheidseienskappe en selfkonsep. 
In hierdie studie is ondersoek ingestel na die persoonlikheidseienskappe van inbelsentrumkonsultante wat werksbevrediging ervaar. Indien vasgestel kan word watter persoonlikheidseienskappe konsultante het wat werksbevrediging ervaar, kan keuring spesifiek op dié eienskappe konsentreer, ten einde konsultante in diens te neem wat enersyds werksbevrediging sal ervaar en andersyds tot voordeel van die organisasie sal wees.

As sodanig word die volgende hipoteses gestel:

Hipotese 1: Daar is 'n statistiese beduidende verskil in die gemiddelde tellings van inbelsentrumkonsultante wat werksbevrediging ervaar teenoor dié wat dit nie ervaar nie, ten opsigte van die persoonlikheidsdimensies soos gemeet deur die Jackson Personality Research Form.

Hipotese 2: Daar is statisties beduidende verbande tussen die dimensies van werksbevrediging enersyds en persoonlikheid andersyds.

Hipotese 3: Daar is statisties beduidende korrelasies tussen ouderdom, jare diens by inbelsentrum en totale jare diens, aan die eenkant, en algemene werkstevredenheid aan die anderkant.

\section{METODE}

\section{Steekproef}

Die toetsing was toegespits op die populasie van 'n inbelsentrum by ' $n$ organisasie in die gesondheidsorgindustrie. Diens aan kliënte is in ses afdelings verdeel en konsultante vanuit al ses die afdelings is vir die steekproef gebruik. 'n Steekproef van 104 inbelsentrumkonsultante wat verteenwoordigend van die populasie is in terme van kultuurgroep, geslag en ouderdom, is getrek - daar is later bevind dat 103 van die vraelyste volledig was.

Die steekproef bestaan uit 40 mans $(38,5 \%)$ en 64 vroue $(61,5 \%)$ Die ouderdomme van die inbelsentrumkonsultante het gewissel van 20 tot 36 jaar, met 'n gemiddelde ouderdom van 25,2 jaar. Die meerderheid van die respondente was ten tye van die meting werksaam in die Kliëntediens- (27,2\%) en Vitality- $(26,0 \%)$ inbelsentrum. Deelname vanuit ander afdelings was soos volg: Makelaars (2\%); Debietorder (13,5\%); Internet (5,8\%) en Verskaffers $(14,5 \%)$. Die aantal jare wat die konsultante in die maatskappy se inbelsentrum werksaam was, het gewissel van een maand $(2,9 \%)$ tot 49 maande $(1,0 \%)$. Die huistaal van die meeste respondente was Engels (76,9\%), gevolg deur Afrikaans $(11,5 \%)$, Zulu $(3,8 \%)$, Sotho $(3,8 \%)$, Xhosa $(1,9 \%)$ en Tswana $(1,9 \%)$. Die verdeling in terme van kultuurgroepe was soos volg: 46 Wit (44,2\%); 29 Asiërs (27,9\%); 18 Swart $(17,3 \%)$ en 11 Bruin $(10,6 \%)$.

\section{Meetinstrumente}

Die twee instrumente wat gebruik is vir die studie, is die Minnesota Satisfaction Questionnaire (MSQ) en die Jackson Personality Research Form (PRF-E).

Die Minnesota Satisfaction Questionnaire (MSQ) is ontwerp om werksbevrediging by 'n persoon te meet (In Minnesota Satisfaction Questionnaire, geen datum, p. 1). Die toets is tans in drie vorms beskikbaar: twee lang vorms (1997- en 1967-uitgawes) en 'n verkorte vorm. Die MSQ is 'n papier-en-potlood-vraelys wat die mate meet waarin beroepsbehoeftes en waardes in die werk bevredig word. Die toets kan toegepas word op groepe of individue. Daar is twintig hoofbronne van werksbevrediging (genoem werksbevredigers) in die werksomgewing geidentifiseer. Die twintig MSQ-subskale is elk gebaseer op een van die werksbevredigers (Lew, 1997, p. 111) te wete: die gebruik van vermoëns; prestasie; aktiwiteite; bevordering; outoriteit; organisasiebeleid en -praktyke; vergoeding; medewerkers; kreatiwiteit; onafhanklikheid; morele waardes; erkenning; verantwoordelikheid; sekuriteit; sosiale diens; sosiale status; toesighouding - menslike verhoudinge; toesighouding - tegnies; werkverskeidenheid en fisieke werkstoestande. 'n Onderskeid is gemaak tussen twee komponente van die MSQ, naamlik intrinsieke en ekstrinsieke bevrediging. Die outeurs van die MSQ rapporteer ' $n$ interne betroubaarheidskoëffisient van 0,86 vir intrinsieke bevrediging, 0,80 vir ekstrinsieke bevrediging en 0,90 vir algemene bevrediging (Lew, 1997, p. 192). Vir die doel van hierdie navorsing is die lang vorm gebruik.

TABEL 1

BIOGRAFIESE INLIGTING VAN DIE RESPONDENTE

\begin{tabular}{|c|c|c|}
\hline DEMOGRAFIESE VERANDERLIKES & FREKWENSIE & PERSENTASIE \\
\hline \multicolumn{3}{|l|}{ GESLAG } \\
\hline Manlik & 40 & $38,5 \%$ \\
\hline Vroulik & 64 & $61,5 \%$ \\
\hline Totaal & 104 & $100,0 \%$ \\
\hline \multicolumn{3}{|l|}{ OUDERDOM } \\
\hline $20-21$ jaar & 11 & $10,6 \%$ \\
\hline $22-23$ jaar & 22 & $21,1 \%$ \\
\hline $24-25$ jaar & 33 & $31,8 \%$ \\
\hline $26-27$ jaar & 16 & $15,4 \%$ \\
\hline $28-29$ jaar & 12 & $11,6 \%$ \\
\hline $30-31$ jaar & 5 & $4,8 \%$ \\
\hline $32-34$ jaar & 3 & $2,9 \%$ \\
\hline 36 jaar & 2 & $1,9 \%$ \\
\hline Totaal & 104 & $100,0 \%$ \\
\hline \multicolumn{3}{|l|}{ TIPE INBELSENTRUM } \\
\hline Uitgaande & 9 & $8,7 \%$ \\
\hline Inkomende & 95 & $91,3 \%$ \\
\hline Totaal & 104 & $100,0 \%$ \\
\hline \multicolumn{3}{|l|}{ AFDELING IN DIE INBELSENTRUM } \\
\hline Makelaar & 2 & $2,0 \%$ \\
\hline Kliëntediens & 40 & $38,2 \%$ \\
\hline Debiet Order & 14 & $13,5 \%$ \\
\hline Internet & 6 & $5,8 \%$ \\
\hline Verskaffer & 15 & $14,5 \%$ \\
\hline Vitality & 27 & $26,0 \%$ \\
\hline Totaal & 104 & $100,0 \%$ \\
\hline MAANDE DIENS 1 - 4 maande & 19 & $18,4 \%$ \\
\hline 5 - 8 maande & 19 & $18,3 \%$ \\
\hline 9-12 maande & 20 & $19,2 \%$ \\
\hline 13 - 16 maande & 5 & $4,8 \%$ \\
\hline 17 - 20 maande & 10 & $9,5 \%$ \\
\hline 21 - 24 maande & 13 & $12,5 \%$ \\
\hline 25 - 28 maande & 5 & $4,8 \%$ \\
\hline 29 - 32 maande & 4 & $3,8 \%$ \\
\hline 33 - 36 maande & 6 & $5,8 \%$ \\
\hline 43 - 49 maande & 3 & $3,0 \%$ \\
\hline Totaal & 104 & $100,0 \%$ \\
\hline \multicolumn{3}{|l|}{ HUISTAAL } \\
\hline Engels & 80 & $76,9 \%$ \\
\hline Afrikaans & 12 & $11,5 \%$ \\
\hline Zulu & 4 & $3,8 \%$ \\
\hline Xhosa & 2 & $1,9 \%$ \\
\hline Sesotho & 4 & $3,8 \%$ \\
\hline Tswana & 2 & $1,9 \%$ \\
\hline Totaal & 104 & $100,0 \%$ \\
\hline \multicolumn{3}{|l|}{ ETNIESE GROEPERING } \\
\hline Swart & 18 & $17,3 \%$ \\
\hline Wit & 46 & $44,2 \%$ \\
\hline Bruin & 11 & $10,6 \%$ \\
\hline Asiër & 29 & $27,9 \%$ \\
\hline Totaal & 104 & $100,0 \%$ \\
\hline
\end{tabular}


TABEL 2

Persoonlikheidskonstrukte van Jackson SE Personality RESEARCH FORM (PRF=E)

\begin{tabular}{ll}
\hline Dimensie & Beskrywing \\
\hline Teruggetrokkenheid & $\begin{array}{l}\text { 'n Hoë mate van nederigheid; aanvaar skuld en } \\
\text { kritiek selfs as hy/sy dit nie verdien nie; gewillig } \\
\text { om 'n ondergeskikte rol te aanvaar }\end{array}$
\end{tabular}

Prestasie

Strewe om moeilike take uit te voer; handhaaf hoë standaarde en is bereid om te werk met ' $n$ toekomstige doel voor oё; reageer positief op kompetisie

Affiliasie

Geniet dit om saam met vriende te wees en mense in die algemeen; wend 'n poging aan om vriendskappe te bou en goeie verhoudinge met mense te handhaaf

Aggressie

Geniet stryery en argumentering; soms bereid om mense seer te maak om sy/haar sin te kry

Outonomie

Probeer wegbreek van enige beperkings; geniet dit om onverbonde en vry te wees van mense, plekke en verpligtinge en kan opstandig wees indien hy/sy gekonfronteer word met beperkings

Verandering

Geniet nuwe en verskillende ervarings; hou nie van roetine nie en kan opinies en waardes geredelik verander in verskillende situasies

Kognitiewe struktuur Hou nie van dubbelsinnigheid of onduidelike inligting nie; wil besluite maak gebaseer op definitiewe kennis eerder as raaiskote of waarskynlikhede

Verdediging

Gereed om homself/haarself teen werklike of verbeelde skade te verdedig; is liggeraak en aanvaar nie maklik kritiek nie

Dominansie

Poog om sy/haar omgewing te beheer en ander mense te beinvloed; spreek opinies sterk uit

Uithouvermoë

Uitbundigheid

Risikovermyding

Impulsiwitiet

Simpatie

Georganiseerdheid

Sosialiteit

Bereid om lang ure te werk; gee nie maklik tou op nie; geduldig en onversetlik in werkgewoontes

Wil die middelpunt van belangstelling wees; geniet dit om 'n gehoor te hê en kan dit geniet om dramaties of snedig te wees

Geniet nie opwindende aktiwiteite nie, veral as dit gevaarlik is; probeer persoonlike veiligheid maksimeer

Geneig om sonder om te dink op te tree; gee gereeld uiting aan gevoelens en wense

Gee simpatie en versorging; help ander waar moontlik; doen maklik gunse vir ander

Gesteld op netheid en georganiseerdheid van persoonlike goed en omgewing; geïnteresseerd in maniere om materiaal metodologies georganiseerd te hou

Doen verskeie dinge net vir die grap daarvan; spandeer heelwat tyd deur deelname aan speletjies, sport, sosiale aktiwiteite en ander vermaaklikheid; handhaaf 'n lighartige houding jeens die lewe

Visuele verskynsels Merk reuke, klanke, waarnemings, smake en die gevoel van dinge op; onthou die sensasies en glo dat dit ' $n$ belangrike deel van die lewe is

Sosiale erkenning Verlang om hooggeag te word deur kennisse; besorgd oor reputasie en wat ander mense van hom/haar dink; werk vir goedkeuring en erkenning van ander

Afhanklikheid

Soek gereeld simpatie, beskerming, liefde, advies en versekering van ander mense; voel onseker of hulpeloos sonder dié ondersteuning

Kennisingesteldheid Wil verskeie velde van kennis verstaan; sy/haar waardes is 'n samestelling van idees, bevestigbare veralgemenings en logiese denke

Sosiale wenslikheid

Beskryf homself/haarself in wenslike terme, bewustelik of onbewustelik; bied 'n gunstige beeld van homself/haarself aan in reaksie op stellings oor sy/haar persoonlikheid
Die Personality Research Form (PRF) weerspieël die tegnologiese vooruitgang wat gemaak is in terme van toetskonstruksie (Anastasi, 1990, p. 546). Die toets van Jackson is teoreties gefundeer op Murray se persoonlikheidsteorie wat toegespits is op normale eerder as patologiese persoonlikheidseienskappe. Die instrument bestaan uit 352 waar/vals-items en 22 persoonlikheidskale wat routellings van 0 (minimum) tot 16 (maksimum) lewer. Twee geldigheidskale, naamlik sosiale wenslikheid en konsekwentheid, is ingesluit om sosiale wenslikheid en interne konsekwentheid van die antwoorde te toets (Anastasi, 1990, p. 546). Die persoonlikheidskonstrukte wat deur die toets gemeet word, is faktor-analities bepaal. Die persoonlikheidskale tesame met 'n kort beskrywing van die betekenis van hoë tellings van die PRF-E (Jackson, 1989, p.6) word in Tabel 2 uiteengesit:

Die Persoonlikheidsnavorsingsvorm is 'n tegnies gefundeerde instrument wat voldoen aan navorsingsvereistes ten opsigte van betroubaarheid en geldigheid. Die Spearman-Brown formule lewer betroubaarhede vir die PRF-E skale wat strek van 0,50 tot 0,91 , vir 'n steekproef van kollegestudente (Jackson, 1989, p. 41). Dit blyk egter uit die handleiding dat vyftien van die twee-en-twintig skale betroubaarhede laer as 0.75 het.

\section{Prosedure}

Departementshoofde in die onderskeie afdelings is genader om toestemming te verkry om die twee vraelyste af te neem. Die belangrikheid en voordele van die resultate van so 'n studie is uitgewys om goedkeuring van die departementshoofde te verkry. Daarna is die spanleiers genader om behulpsaam te wees om hul onderskeie spanne te laat deelneem aan die toetsprogram. Die proefpersone het die toetse vrywillig afgelê. Die MSQ- en Jackson se PRF, tesame met 'n biografiese vraelys, is aan die proefpersone gegee. Albei vraelyste is in Engels afgeneem, aangesien dit 'n Engelssprekende organisasie is en alle werknemers Engels magtig is. Die proefpersone is ingelig dat ofskoon die organisasie kennis sal dra van die oorhoofse resultate van die studie, dit geensins toegang sal hê tot individuele rekords nie.

\section{RESULTATE}

Die resultate van elke meetinstrument word vervolgens in meer besonderhede bespreek.

\section{Minnesota Satisfaction Questionnaire (MSQ)}

Ten einde die struktuur van die MSQ te bepaal, is die 20 skale wat elk gebaseer is op 5 items, geinterkorreleer en aan 'n hooffaktorontleding onderwerp $(\mathrm{N}=103)$ : Volgens Tabel 3 is twee eigenwaardes groter as een, gevolglik is twee faktore onttrek en na eenvoudige struktuur geroteer met behulp van die Direct Oblimin-rotasie. Die geroteerde faktormatriks word in Tabel 4 gegee.

Die interkorrelasies van die faktore verskyn in Tabel 5.

Uit 'n inspeksie van Tabel 5 blyk dit dat Faktore 1 en 2 matig hoog korreleer. Faktor 1 hou verband met die aard van die werk. Faktor 2 hou verband met menseverhoudinge. Dit is nie onverwags dat die twee faktore onderling hoog korreleer nie, aangesien albei medebepalend is van werkstevredenheid.

Aangesien die twee faktore hoog korreleer met mekaar, is besluit om slegs een faktor te onttrek wat al die toetsitems insluit. 'n Tweede faktorontleding is gedoen. Die faktormatriks verskyn in Tabel 6.

Uit Tabel 6 blyk dit dat al 100 items op die een faktor laai. Dit dui op 'n dimensie van algemene werkstevredenheid. 
Volgens Cronbach se koëffisient alfa is die betroubaarheid van die skaal onderliggend aan die faktor 0,987.

TABel 3

EIGENWAARDES VAN DIE ONGEREDUSEERDE INTERKORRELASIEMATRIKS (MSQ)

\begin{tabular}{cc}
\hline WORTEL & EIGENWAARDE \\
\hline 1 & 13,294 \\
2 & 1,272 \\
3 & 0,866 \\
4 & 0,705 \\
5 & 0,566 \\
6 & 0,509 \\
7 & 0,386 \\
8 & 0,325 \\
9 & 0,318 \\
10 & 0,289 \\
11 & 0,258 \\
12 & 0,218 \\
13 & 0,187 \\
14 & 0,164 \\
15 & 0,142 \\
16 & 0,134 \\
17 & 0,111 \\
18 & 0,106 \\
19 & 0,078 \\
20 & 0,073 \\
SPOOR & 20,000 \\
\hline
\end{tabular}

TABEL 4

GEROTEERDE FAKTORMATRIKS VAN DIE MSQ (DIRECT OBLIMIN ROTASIE)

\begin{tabular}{lccc}
\hline & FAKTOR $\mathbf{1}$ & FAKTOR 2 & $\mathbf{h}^{2} \mathbf{j}$ \\
\hline Gebruik van vermoëns & $\mathbf{0 , 9 3 4}$ & $-0,085$ & 0,778 \\
Prestasie & $\mathbf{0 , 7 6 7}$ & 0,189 & 0,808 \\
Aktiwiteit & $\mathbf{0 , 7 7 0}$ & 0,133 & 0,740 \\
Bevordering & $\mathbf{0 , 5 9 9}$ & 0,317 & 0,700 \\
Outoriteit & $\mathbf{0 , 7 8 7}$ & $-0,054$ & 0,569 \\
Organisasiebeleid en -praktyke & $\mathbf{0 , 5 1 7}$ & 0,380 & 0,661 \\
Vergoeding & $\mathbf{0 , 5 7 7}$ & 0,367 & 0,735 \\
Medewerkers & $\mathbf{0 , 5 2 7}$ & 0,258 & 0,516 \\
Kreatiwiteit & $\mathbf{0 , 9 5 2}$ & $-0,066$ & 0,831 \\
Onafhanklikheid & $\mathbf{0 , 8 6 2}$ & $-0,140$ & 0,609 \\
Morele waardes & $\mathbf{0 , 7 6 9}$ & 0,067 & 0,661 \\
Erkenning & $\mathbf{0 , 5 0 5}$ & 0,436 & 0,724 \\
Verantwoordelikheid & $\mathbf{0 , 8 3 0}$ & 0,077 & 0,776 \\
Sekuriteit & $\mathbf{0 , 4 8 5}$ & 0,461 & 0,731 \\
Sosiale diens & $\mathbf{0 , 7 4 2}$ & 0,104 & 0,659 \\
Sosiale status & $\mathbf{0 , 8 1 2}$ & 0,041 & 0,703 \\
Toesighouding - Menslike verhoudinge & $\mathbf{0 , 0 1 4}$ & $\mathbf{0 , 8 3 5}$ & 0,712 \\
Toesighouding - Tegnies & $\mathbf{0 , 1 4 3}$ & $\mathbf{0 , 7 7 1}$ & 0,755 \\
Werksverskeidenheid & $\mathbf{1 , 0 3 6}$ & $-0,230$ & 0,826 \\
Fisieke werkstoestande & $\mathbf{0 , 5 0 4}$ & 0,275 & 0,506 \\
\hline
\end{tabular}

Jackson se Personality Research Form (JPRF)

Dieselfde prosedure as in die geval van die MSQ, is vir die verwerking van die gegewens van die Jackson PRF gebruik. Jackson se 22 persoonlikheidskale is geinterkorreleer en aan 'n hooffaktorontleding onderwerp $(\mathrm{N}=103)$. Die eigenwaardes van die interkorrelasiematriks (22 x 22) verskyn in Tabel 7.
TABEL 5

MATRIKS VAN INTERKORRELASIES VAN GEROTEERDE FAKTORE

\begin{tabular}{lcc}
\hline & FAKTOR 1 & FAKTOR 2 \\
\hline FAKTOR 1 & 1,000 & 0,633 \\
FAKTOR 2 & 0,633 & 1,000 \\
\hline
\end{tabular}

TABEL 6

FAKTORMATRIKS VAN DIE MSQ

\begin{tabular}{lcc}
\hline & FAKTOR $\mathbf{1}$ & $\mathbf{h}^{2} \mathbf{j}$ \\
\hline Gebruik van vermoëns & 0,849 & 0,721 \\
Prestasie & 0,900 & 0,810 \\
Aktiwiteit & 0,860 & 0,739 \\
Bevordering & 0,833 & 0,693 \\
Outoriteit & 0,731 & 0,534 \\
Organisasiebeleid en -praktyke & 0,800 & 0,640 \\
Vergoeding & 0,849 & 0,720 \\
Medewerkers & 0,716 & 0,513 \\
Kreatiwiteit & 0,882 & 0,779 \\
Onafhanklikheid & 0,736 & 0,542 \\
Morele waardes & 0,808 & 0,652 \\
Erkenning & 0,830 & 0,688 \\
Verantwoordelikheid & 0,875 & 0,766 \\
Sekuriteit & 0,829 & 0,687 \\
Sosiale diens & 0,810 & 0,656 \\
Sosiale status & 0,830 & 0,688 \\
Toesighouding - Menslike verhoudinge & 0,641 & 0,411 \\
Toesighouding - Tegnies & 0,720 & 0,519 \\
Werksverskeidenheid & 0,835 & 0,697 \\
Fisieke werkstoestande & 0,708 & 0,501 \\
\hline & &
\end{tabular}

TABEL 7

EIGENWAARDES VAN DIE ONGEREDUSEERDE INTERKORRELASIEMATRIKS (JPRF)

\begin{tabular}{cc}
\hline WORTEL & EIGENWAARDE \\
\hline 1 & 8,114 \\
2 & 1,463 \\
3 & 1,185 \\
4 & 1,153 \\
5 & 1,009 \\
6 & 0,981 \\
7 & 0,934 \\
8 & 0,861 \\
9 & 0,766 \\
10 & 0,715 \\
11 & 0,701 \\
12 & 0,656 \\
13 & 0,525 \\
14 & 0,452 \\
15 & 0,401 \\
16 & 0,388 \\
17 & 0,373 \\
18 & 0,345 \\
19 & 0,290 \\
20 & 0,254 \\
21 & 0,238 \\
22 & 0,195 \\
SPOOR & 22,000 \\
\hline & \\
\hline &
\end{tabular}


Volgens Tabel 7 is daar vyf eigenwaardes groter as een, gevolglik is vyf faktore onttrek en na eenvoudige struktuur geroteer met behulp van die Direct Obliminrotasie. Die resultate van die geroteerde faktormatriks word in Tabel 8 gegee.

TABEL 8

GEROTEeRde FAKTORMATRIKS VAN JACKSON SE PRF (DIRECT OBLIMIN ROTASIE)

\begin{tabular}{|c|c|c|c|c|c|c|}
\hline & $\begin{array}{c}\text { FAKTOR } \\
1\end{array}$ & $\begin{array}{c}\text { FAKTOR } \\
2\end{array}$ & $\begin{array}{c}\text { FAKTOR } \\
3\end{array}$ & $\begin{array}{c}\text { FAKTOR } \\
4\end{array}$ & $\begin{array}{c}\text { FAKTOR } \\
5\end{array}$ & $h^{2} j$ \\
\hline Aggressie & 0,638 & 0,006 & 0,121 & $-0,077$ & 0,079 & 0,529 \\
\hline Uitbundigheid & 0,548 & $-0,006$ & $-0,129$ & 0,241 & 0,180 & 0,517 \\
\hline Kognitiewe struktuur & 0,548 & $-0,013$ & 0,041 & 0,061 & 0,057 & 0,387 \\
\hline Verdediging & 0,505 & 0,274 & $-0,024$ & $-0,086$ & 0,126 & 0,486 \\
\hline Simpatie & 0,478 & 0,002 & 0,136 & 0,083 & 0,037 & 0,372 \\
\hline Risiko vermyding & 0,414 & 0,178 & 0,063 & 0,224 & 0,127 & 0,543 \\
\hline Sosiale wenslikheid & $-0,023$ & 0,950 & $-0,001$ & $-0,077$ & $-0,003$ & 0,871 \\
\hline Konsekwentheid & 0,048 & 0,287 & 0,033 & 0,143 & 0,160 & 0,235 \\
\hline Affiliasie & 0,134 & 0,212 & 0,188 & 0,198 & 0,164 & 0,389 \\
\hline Teruggetrokkenheid & $-0,033$ & 0,031 & 0,725 & $-0,054$ & 0,029 & 0,525 \\
\hline Waarnemingsvermoë & 0,073 & $-0,199$ & 0,531 & 0,388 & 0,170 & 0,644 \\
\hline Impulsiwiteit & 0,322 & 0,157 & 0,386 & 0,115 & $-0,177$ & 0,416 \\
\hline Dominansie & 0,210 & 0,184 & 0,349 & 0,077 & 0,029 & 0,402 \\
\hline Kennisingesteldheid & 0,093 & $-0,012$ & 0,104 & 0,573 & 0,119 & 0,500 \\
\hline Verandering & 0,318 & 0,294 & $-0,032$ & 0,419 & 0,047 & 0,576 \\
\hline Outonomie & 0,263 & 0,158 & 0,328 & $-0,356$ & 0,195 & 0,465 \\
\hline Sosialiteit & 0,143 & 0,108 & 0,129 & 0,205 & 0,186 & 0,296 \\
\hline Uithouvermoë & $-0,008$ & 0,074 & 0,046 & 0,046 & 0,681 & 0,557 \\
\hline Sosiale erkenning & 0,315 & $-0,142$ & 0,038 & $-0,108$ & 0,632 & 0,614 \\
\hline Prestasie & 0,139 & 0,030 & $-0,107$ & 0,077 & 0,603 & 0,482 \\
\hline Afhanklikheid & $-0,197$ & 0,269 & 0,203 & 0,091 & 0,497 & 0,493 \\
\hline Georganiseerdheid & 0,096 & 0,079 & 0,202 & 0,087 & 0,274 & 0,300 \\
\hline
\end{tabular}

Die interkorrelasies tussen die vyf faktore verskyn in Tabel 9.

TABEL 9

MATRIKS VAN INTERKORRELASIES VAN GEROTEERDE FAKTORE

\begin{tabular}{lccccc}
\hline & FAKTOR & FAKTOR & FAKTOR & FAKTOR & FAKTOR \\
& 1 & 2 & 3 & 4 & 5 \\
\hline FAKTOR 1 & 1,000 & 0,343 & 0,452 & 0,348 & 0,567 \\
FAKTOR 2 & 0,343 & 1,000 & 0,418 & 0,147 & 0,393 \\
FAKTOR 3 & 0,452 & 0,418 & 1,000 & 0,237 & 0,407 \\
FAKTOR 4 & 0,348 & 0,147 & 0,237 & 1,000 & 0,346 \\
FAKTOR 5 & 0,567 & 0,393 & 0,407 & 0,346 & 1,000 \\
\hline
\end{tabular}

Die betroubaarhede van die vyf skale onderliggend aan die faktore is volgens Cronbach se koëffisient alfa (á) bepaal: Faktor 1 á $=0,768$, Faktor 2 á $=0,523$, Faktor 3 á $=0,697$, Faktor 4 á $=0,614$ en Faktor 5 á =0,744. Tabel 9 dui daarop dat daar onderling hoë korrelasies tussen die faktore bestaan. Uit Tabel 8 is dit duidelik dat Faktore 1,3,4 en 5 drie of meer hoë ladings het en derhalwe goed bepaal is. Faktor 2 het slegs een hoë lading en twee lae ladings, wat daarop dui dat Faktor 2 swak bepaal is. Aangesien die faktore onderling hoog korreleer (Tabel 9) en omdat Faktor 2 betreklik swak bepaal is (Tabel 8), is besluit om vervolgens vier faktore te onttrek en te roteer na eenvoudige struktuur.

Die vierfaktoroplossing verskyn in Tabel 10.
TABel 10

Geroteerde faKtormatriks VAN JACKSON SE PRF (DIRECT OBLIMIN ROTASIE)

\begin{tabular}{|c|c|c|c|c|c|}
\hline & $\begin{array}{c}\text { FAKTOR } \\
1\end{array}$ & $\begin{array}{c}\text { FAKTOR } \\
2\end{array}$ & $\begin{array}{c}\text { FAKTOR } \\
3\end{array}$ & $\begin{array}{c}\text { FAKTOR } \\
4\end{array}$ & $\mathbf{h}^{2} \mathbf{j}$ \\
\hline Aggressie & 0,729 & $-0,050$ & 0,129 & $-0,030$ & 0,528 \\
\hline Sosiale erkenning & 0,617 & 0,189 & $-0,215$ & 0,030 & 0,533 \\
\hline Kognitiewe struktuur & 0,608 & $-0,090$ & 0,066 & 0,085 & 0,390 \\
\hline Uitbundigheid & 0,607 & $-0,090$ & $-0,132$ & 0,260 & 0,507 \\
\hline Verdediging & 0,550 & 0,237 & 0,071 & $-0,123$ & 0,464 \\
\hline Simpatie & 0,520 & $-0,050$ & 0,140 & 0,124 & 0,376 \\
\hline Risiko vermyding & 0,426 & 0,180 & 0,076 & 0,238 & 0,523 \\
\hline Outonomie & 0,417 & 0,309 & 0,216 & $-0,281$ & 0,433 \\
\hline Prestasie & 0,407 & 0,329 & $-0,327$ & 0,116 & 0,495 \\
\hline Sosiale wenslikheid & $-0,050$ & 0,721 & 0,214 & $-0,160$ & 0,553 \\
\hline Afhanklikheid & $-0,060$ & 0,678 & $-0,030$ & 0,173 & 0,504 \\
\hline Uithouvermoë & 0,287 & 0,470 & $-0,222$ & 0,129 & 0,511 \\
\hline Konsekwentheid & 0,037 & 0,375 & 0,028 & 0,146 & 0,230 \\
\hline Affiliasie & 0,166 & 0,316 & 0,120 & 0,241 & 0,388 \\
\hline Georganiseerdheid & 0,208 & 0,285 & 0,043 & 0,155 & 0,294 \\
\hline Impulsiwiteit & 0,235 & 0,071 & 0,439 & 0,182 & 0,437 \\
\hline Teruggetrokkenheid & 0,051 & 0,243 & 0,413 & 0,132 & 0,366 \\
\hline Dominansie & 0,214 & 0,243 & 0,289 & 0,151 & 0,403 \\
\hline Kennisingesteldheid & 0,015 & 0,072 & 0,012 & 0,689 & 0,528 \\
\hline Waarnemingsvermoë & 0,161 & 0,050 & 0,216 & 0,559 & 0,550 \\
\hline Verandering & 0,233 & 0,241 & 0,063 & 0,366 & 0,481 \\
\hline Sosialiteit & 0,181 & 0,220 & 0,049 & 0,262 & 0,298 \\
\hline
\end{tabular}

Uit Tabel 10 blyk dit dat Faktor 1 goed bepaal is. Faktore 2,3 en 4 is redelik goed bepaal. Daar is derhalwe volstaan met die vierfaktoroplossing. Verdere ondersoek dui daarop dat Faktor 1 hoë ladings het op aggressie, sosiale erkenning, kognitiewe struktuur, uitbundigheid, verdediging en simpatie. Hierdie ladings dui op 'n selfgeldende tipe persoonlikheid (hierdie afleiding is gemaak deur die beskrywings van die skale in ag te neem en nie slegs die benamings nie). Faktor 2 hou verband met afhanklikheid van ander mense. Faktor 3 hou verband met impulsiwiteit en Faktor 4 hou verband met 'n soeke na kennis. Vervolgens is vier skale gevorm ooreenstemmend met die vier faktore.

Betroubaarheid van die skale is volgens Cronbach se koëffisient alfa bepaal: Skaal 1 á $=0,853$, Skaal 2 á $=0,756$, Skaal 3 á $=$ 0,649 en Skaal 4 á $=0,734$.

Vervolgens is ' $\mathrm{n}$ mediaansnit op die MSQ geneem om twee kontrasterende groepe te vorm. Die tevrede- $(\mathrm{N}=51)$ en ontevrede $(\mathrm{N}=52)$ groepe is vergelyk ten opsigte van die vier skale van die Jackson PRF, dog het geen beduidende resultate gelewer nie.

Die resultate van die beduidenheid van die verskille tussen die twee groepe word in Tabel 11 gerapporteer.

Vervolgens is die vier skale van die Jackson PRF gekorreleer met die dimensies van die MSQ. Slegs een van die korrelasies was statisties beduidend en wel tussen Skaal 1 van die Jackson PRF en dimensie 19 (werksverskeidenheid) van die MSQ. Geen van die ander korrelasies was statisties beduidend nie. 'n Statisties beduidende negatiewe korrelasie is verkry met $(r=0,199$ en $p=$ 0,043 ). Soos reeds genoem, dui Skaal 1 van die Jackson PRF op ' $n$ selfgeldende tipe persoonlikheid. 'n Selfgeldende tipe persoonlikheid is dus veral ontevrede met die verskeidenheid van werk in die inbelsentrum.

'n Profiel van die MSQ tellings per skaal is getrek, ten einde lae en hoë tellings te kontrasteer. Figuur 1 illustreer die verspreiding van die onderskeie MSQ dimensies se tellings op 'n skaal van 0 tot 25 , met 0 die mees ontevrede en 25 die mees tevrede. 
TABEL 11

VERGELYKING VAN GEMIDDELDES VAN DIE TEVREDE- EN ONTEVREDE GROEPE TEN OPSIGTE VAN DIE JACKSON PRF

\begin{tabular}{|c|c|c|c|c|c|c|c|c|c|c|c|c|}
\hline \multirow[t]{2}{*}{ VERANDERLIKE } & \multicolumn{3}{|c|}{$\begin{array}{c}\text { Tevrede } \\
\text { groep }\end{array}$} & \multicolumn{2}{|c|}{$\begin{array}{c}\text { Ontevrede } \\
\text { groep }\end{array}$} & \multirow[b]{2}{*}{ N2 } & \multirow[t]{2}{*}{$\begin{array}{l}\text { LEVENE } \\
\text { F }\end{array}$} & \multirow[t]{2}{*}{$\begin{array}{l}\text { GRADE VAN } \\
\text { VRYHEID }\end{array}$} & \multirow[t]{2}{*}{$\mathrm{p}(\mathrm{F})$} & \multirow[t]{2}{*}{ t-waarde } & \multirow[t]{2}{*}{$\begin{array}{l}\text { GRADE VAN } \\
\text { VRYHEID }\end{array}$} & \multirow[t]{2}{*}{$\mathrm{p}(\mathrm{t})$} \\
\hline & $\overline{\mathrm{X}}_{1}$ & S1 & N1 & $\bar{X}_{2}$ & S2 & & & & & & & \\
\hline PRF 1 & 207,22 & 12,52 & 51 & 209,50 & 13,88 & 52 & 0,48 & 1,101 & 0,49 & 0,88 & 101 & 0,38 \\
\hline PRF 2 & 137,69 & 9,48 & 51 & 137,60 & 7,20 & 52 & 3,94 & 1,101 & $0,05^{*}$ & $-0,05$ & 101 & 0,96 \\
\hline PRF 3 & 68,29 & 5,23 & 51 & 68,52 & 5,17 & 52 & 0,24 & 1,101 & 0,63 & 0,22 & 101 & 0,83 \\
\hline PRF 4 & 93,45 & 6,87 & 51 & 92,83 & 6,58 & 52 & 0,30 & 1,101 & 0,59 & $-0,47$ & 101 & 0,64 \\
\hline
\end{tabular}

Hotelling $\mathrm{T}^{2}=0,031$

F-waarde $=0,756$

Grade van vryheid $=4,98$

$\mathrm{p}=0,557$

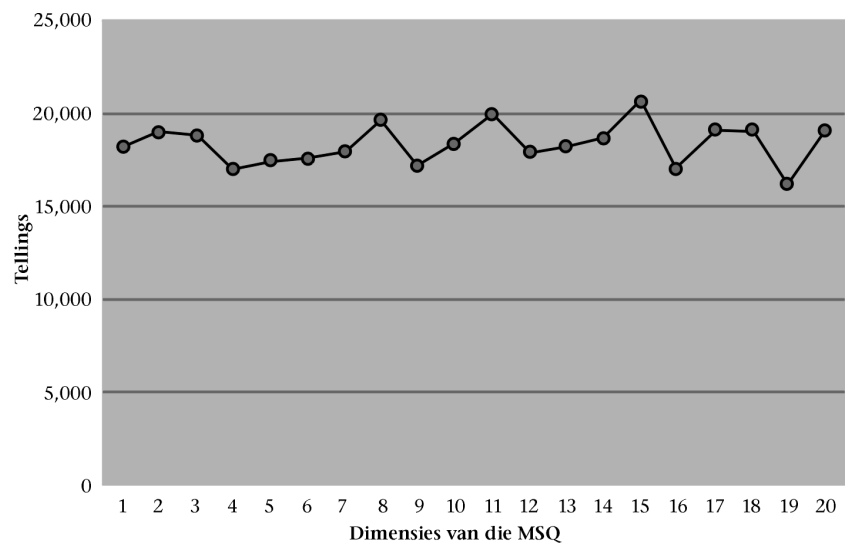

Figuur 1: Verspreiding van tellings van die MSQ

Dit blyk dat inbelsentrumkonsultante oor die algemeen tevrede is met hul werk -'n gemiddelde telling van 18,549 uit 'n maksimum 25 is ' $n$ aanduiding daarvan. Dimensies wat hoër as die gemiddeld is en waarmee konsultante dus tevrede is, is medewerkers, morele waardes, sosiale diens, toesighouding (menslike verhoudinge, toesighouding) en tegniese en fisieke werkstoestande. Hierdie dimensies hou verband met kollegialiteit in die werkplek. Aspekte waarmee die konsultante relatief minder tevrede is, is bevordering, kreatiwiteit, erkenning, sosiale status en werkverskeidenheid. Werkverskeidenheid het die laagste telling gelewer - 16,388 uit 'n moontlike 25 .

Die MSQ totaaltelling is voorts gekorreleer met ouderdom, jare by inbelsentrum en jare diens. Slegs drie van die korrelasies was statisties beduidend. Eerstens is daar ' $n$ statisties beduidende korrelasie gevind tussen 'n persoon se ouderdom en hoe lank hy in die inbelsentrum werk $(r=0,383$ en $p<0,001)$. Hierdie korrelasie spreek vanself - 'n jong konsultant kon nog nie lank in die inbelsentrum gewerk het nie. Tweedens het ouderdom 'n statisties beduidende negatiewe korrelasie met die totaaltelling van die MSQ gelewer $(r=-0,217$ en $p=0,028)$. Hoe ouer ' $n$ persoon is hoe minder tevrede is hy in die geheel met werk in die inbelsentrum. 'n Statisties beduidende negatiewe korrelasie is laastens gelewer tussen totale jare diens en die totaaltelling van die MSQ ( $r=-0,246$ en $p=0,012)$. Hoe langer ' $n$ persoon dus werksaam is in die inbelsentrum, hoe laer is sy/haar algemene vlak van werksbevrediging.

\section{BESPREKING}

$\mathrm{Na}$ aanleiding van die literatuurstudie en die doelstellings van die ondersoek was die fokus van die studie daarop gerig om die verband tussen die persoonlikheid van inbelsentrumkonsultante en hul werksbevrediging, bloot te lê. Daar is egter bevind dat daar nie 'n statisties beduidende verskil bestaan ten opsigte van die persoonlikheidsprofiel van inbelsentrumkonsultante wat werksbevrediging ervaar en dié wat dit nie ervaar nie. Die hipotese ten opsigte van verskille in persoonlikheid tussen inbelsentrumkonsultante wat werksbevrediging ervaar en dié wat nie werksbevrediging ervaar nie, word dus ten opsigte van hierdie steekproef verwerp.

Hoewel daar nie 'n unieke profiel geidentifiseer is nie, is daar bevind dat daar 'n dimensie is wat verband hou met werkstevredenheid. Skaal 1 van die Jackson PRF, wat op 'n selfgeldende tipe persoonlikheid dui, het 'n statisties beduidende negatiewe verband opgelewer ten opsigte van werksverskeidenheid in die inbelsentrum. Die selfgeldende tipe het 'n betreklik hoë behoefte aan verskeidenheid. Hierdie bevinding steun vorige navorsing wat bevestig dat werk met min ruimte vir verskeidenheid oor die algemeen lae werkstevredenheid tot gevolg het, hoewel die studies nie op spesifieke persoonlikheidstipes gefokus het nie (Gruneberg, 1979 , p. 43). Voorafkeuring van die huidige steekproef kon daartoe gelei het dat die variasiewydte ingeperk is en tot gevolg gehad het dat al die korrelasies ingeperk is. Die korrelasies kon dus hoër gewees het as 'n ongeselekteerde groep (wat nie reeds gekeur is nie) gebruik is in die steekproef.

Dit is belangrik vir organisasies om kennis te neem van die resultate ten opsigte van die selfgeldende persoonlikheidstipe en een van die volgende stappe te neem - keuringsinstrumente kan aangepas word om spesifiek op dié tipe profiel klem te lê, sodat organisasie vooraf kan weet watter kandidate 'n selfgeldende persoonlikheidstipe is, andersins kan die organisasie besluit om die inbelsentrumkonsultante se werk te verander om sodoende meer werksverskeidenheid tot gevolg te hê. Albei hierdie opsies sal laer personeelomset tot gevolg hê. Deur selfgeldende persoonlikheidstipes tydens keuring uit te sluit, sal 'n beter passing tussen werk en die posbekleër tot gevolg hê. Indien in ag geneem word dat konsultante met 'n selfgeldende tipe persoonlikheid slegs ontevrede is met die werksverskeidenheid, word aanbeveel dat die werk eerder verander word om by dié tipe konsultante aan te pas.

Aspekte waarmee die konsultante ontevrede is, is bevordering, kreatiwiteit, erkenning, sosiale status en werksverskeidenheid. Werksverskeidenheid het die laagste telling opgelewer. Dié aspekte het hoofsaaklik te make met die aard van die werk. Kreatiwiteit en werksverskeidenheid is verwant aan mekaar en erkenning en bevordering hou verband met mekaar.

Die plat hiërargiese struktuur in inbelsentrums beperk loopbaanontwikkelingsgeleenthede. Dit het tot gevolg dat lae werkstevredenheid ervaar word t.o.v. erkenning en bevordering. 
Die eerste vlak van bevordering in inbelsentrums is om 'n spanleier te word, maar weens die beperkte getal wat benodig word, word dit nie as 'n motiveerder beleef nie.

Werksverskeidenheid hou verband met die aard van die werk. Dit is dus oor die algemeen moeiliker om dié aspek te verander as in die geval van toesighouding en fisieke werkstoestande. Daar word voorgestel dat die huidige posontwerpe van inbelsentrums verbeter word om posrotasie moontlik te maak en sodoende die gebrek aan verskeidenheid en eentonigheid teen te werk. Herzberg (Gruneberg, 1979, p. 130) reken dat posrotasie slegs ' $n$ groter verskeidenheid van eentonige werk aan die individu sal gee, sonder geleentheid vir groei en ontwikkeling. Posrotasie moet derhalwe nie bloot geimplementeer word as 'n korttermynoplossing nie, maar moet 'n groter doel voor oë hê, naamlik die skep van werksverskeidenheid en terselfdertyd ontwikkelingsgeleenthede aan individue bied (Gruneberg, 1979, p. 130). In Training is given greater emphasis $(2000$, p. 1) word meer uitdagende werk as 'n moontlike oplossing vir herhalende werk voorgestel. Tegnologiese ontwikkeling, soos interaktiewe stemresponse en internetgebaseerde dienste kan gebruik word om eenvoudige dienste te verskaf, wat meer tyd sal skep vir inbelsentrumkonsultante om betrokke te raak by meer komplekse take. In hierdie verband kan genoem word dat die tipe tegnologie wat gebruik word 'n funksie is van die organisasie se teikenmark. Indien dit 'n wydverspreide mark is wat diens verskaf aan kliënte van verskillende ouderdomme, geletterdheid en etniese groeperings (soos in die geval van die huidige steekproef), moet rekenaarbeskikbaarheid en -geletterdheid in ag geneem word.

'n Negatiewe korrelasie tussen jare diens en die totaaltelling van die MSQ is gerapporteer. Hoe langer ' $n$ persoon dus werksaam is in ' $n$ inbelsentrum, hoe laer is sy/haar algemene werksbevrediging. Dit kan op uitbranding dui, wat ' $n$ algemene tendens in inbelsentrums is. Hook (2001, p. 1) het navorsing gedoen op 'n steekproef van 566 inbelsentrumkonsultante by 11 verskillende inbelsentrums. Hy het bevind dat werkstevredenheid oor twee jaar met $24 \%$ afgeneem het en stressimptome oor drie jaar van $19 \%$ tot $24 \%$ toegeneem het, wat daarop dui dat uitbranding 'n werklikheid is in inbelsentrums. Daar word voorgestel dat verdere navorsing gedoen word oor die verband tussen persoonlikheid en uitbranding in inbelsentrums, aangesien uitbranding verband hou met werksbevrediging.

'n Kontensieuse vraagstuk rakende inbelsentrumwerk is dat die werk in baie gevalle as bloot tydelik gesien word en dat baie kandidate slegs belangstel in die werk om 'n gaping in hul loopbane te vul (Walkden, 1999 p. 17). Indien konsultante slegs 'n korttermynsiening het van hul werk in die inbelsentrum, kan daar geredeneer word dat dit nutteloos is om groot bedrae geld te spandeer om die behoud van personeel te bevorder as hulle buitendien geen voorneme het om lank in die inbelsentrum te bly nie.

Daar is ook beperkings ten opsigte van die huidige studie. Weens die feit dat die respondente almal by dieselfde organisasie en derhalwe in dieselfde industrie werk, kon veranderlikes soos persoonlikheidseienskappe, wat reeds by keuring geëlimineer is, ' $n$ invloed op die resultate gehad het. ' $n$ Groter verskeidenheid industrieë wat verskillende keuringstegnieke gebruik, kan moontlik 'n duideliker profiel, verwant aan werksbevrediging, na vore bring. Tydsdruk en die lengte van die vraelyste het 'n beperking op die grootte van die steekproef geplaas. Die PRF het in baie opsigte teleurgestel ten opsigte van betroubaarheid en faktorsuiwerheid.

Die voordele van effektiewe inbelsentrums is duidelik. Organisasies moet egter bewus wees van die kostes wat met personeelomset gepaardgaan en daadwerklike stappe neem om dit teë te werk. 'n Oordrewe klem op die nuutste tegnologie maak sin vir besigheid, maar ' $n$ balans tussen tegnologie en mense is ' $n$ belangrike deel van die werk. In hierdie verband behoort organisasies ondersoek in te stel na die verskillende faktore wat werksbevrediging in inbelsentrums beïnvloed, aangesien dit 'n invloed het op personeelomset. In die huidige studie is gepoog om 'n verband te soek tussen persoonlikheid en werksbevrediging. Daar is egter verskeie gebiede waarop 'n inbelsentrum kan konsentreer om uit te vind hoe om die meeste uit sy mense te kry en seker te maak dat hulle bly.

Die uitkoms van die huidige studie was ietwat teleurstellend en kan toegeskryf word aan die lae betroubaarhede van Jackson se Personality Research Form (PRF-E).

\section{VERWYSINGS}

Agent staffing and retention study - final report. (Geen datum), (Aanlyn). Beskikbaar: ttp://www.incoming.com/s2studies.html (2001, September 7).

Agho, O., Price, J.L. \& Mueller, C. W. (1992). Discriminant validity of measures of job satisfaction, positive affectivity and negative affectivity. Journal of Occupational and Organizational Psychology, 65(3), 185-204.

Alleman, G. (2000, Junie 11). Internet customers must be included. Business Times, (Aanlyn). Beskikbaar: http://www. inet.co.za/ng2/siteWide/content/access/1,2039,6348025453-0,00.html (2000, Augustus 8).

Anastasi, A. (1990). Psychological testing. New York: Macmillan.

Beeld verslaggewer. (2000). Sentrum help 650000 kliënte per maand. Beeld, 24 Oktober.

Beresford, B. (1999). Call centres. Productivity, 25(4), 28-29.

Bidoli, M. (1997). Customer service rules. Financial Mail, 1 August, 6.

Blauner, R. (1964). Alienation and freedom - the factory worker and his industry. Chicago: University of Chicago Press.

Business Day verslaggewer. (2000). Didata, Nuance develop voice recognition system for SA. Business Day, 28 September, 23.

Call centre staff "more likely to be stressed". (2000, Mei 11). Financial Times. (Aanlyn). Beskikbaar: http://www.inet. co.za/ng2/siteWide/content/access/1,2039,614113-54530,00.html (2000, Augustus 8).

De Kock, E. \& Schepers, J.M. (1999). Loopbaanankers en werkstevredenheid. Tydskrif vir Bedryfsielkunde, 25(3), 23-30.

Doucet, K. (2000). How am I doing? CMA Management, 74, 11.

Gruneberg, M.M. (1979). Understanding job satisfaction. London: Macmillan Press.

Hakstian, R. \& Scratchley, L. (1999, Maart). Building high performance call center workforce through a scientifically-based selection system, (Aanlyn). Beskikbaar: www.tmcnet.com/ articles/ccsmag/0399/0399hr.htm (2001, Augustus 29).

Harper, D. (2001). The human factor, (Aanlyn). Beskikbaar: http://www.callcentre.co.uk /now/GENERAL/human.htm (2001, September 17).

Hollman, L. (2000, December 19). Do potential consultants have the right stuff? Call center magazine.com, (Aanlyn). Beskikbaar: http://www.callcentermagazine.com/article/ CM20001219S0005 (2001, September 7).

Hook, K. (Geen datum). If you can't take it, then don't work in it, (Aanlyn). Beskikbaar: http://www.callcentre.co.uk/now/ MANAGE/GENERAL/stres3/htm (2001, September 17).

Howarth, C. (1984). The way people work. London: Oxford University Press.

Jackson, D.N. (1989). Personality Research Form Manual. Michigan: Sigma Assessment Systems.

Kanungo, R. N. (1982). Work alienation - an integrative approach. New York: Praeger.

Lew, C.C. (1997). Person-environment congruence, job satisfaction, and job involvement. Ongepubliseerde Magistersverhandeling. Randse Afrikaanse Universiteit, Johannesburg. 
Minnesota Satisfaction Questionnaire. (Geen datum), (Aanlyn). Beskikbaar: http://www/psych.umn.edu.psylabs/vpr/msqinf. htm (2001, September 5).

Nel, Z.J. (1999). The career choice theory of John Holland. In GB Stead \& MB Watson, Career psychology in the South African context. Pretoria: Van Schaick.

O’Brien, L. (2000, Junie 11). Consultants need special qualities. Business Times, (Aanlyn). Besikbaar: http://www.inet.co.za/ g2/siteWide/content/access/1,2039,634795-5453-0,00.html (2000, 8 August)

Plug, C., Louw, D.A.P., Gouws, L.A. \& Meyer, W.F. (1997). Verklarende en vertalende sielkundewoordeboek. Johannesburg: Heinemann.

Rademeyer, D. (1997). A benefits model for the call center strategy. Ongepubliseerde Magistersverhandeling. Randse Afrikaanse Universiteit, Johannesburg.

Read, B.B. (2001, Maart 23). Recipes for effective staffing. Call center magazine.com, (Aanlyn). Beskikbaar:http://www. callcentermagazine.com/article/CCM20010323S0010 (2001, September 7).
Rucker, F. (2001). New tool for local presence and a competitive advantage, (Aanlyn). Beskikbaar: http://www. callcentre.co.uk/now/GENERAL/new_tool.htm (2001 September 17).

Training is given greater emphasis. (2000, Junie 9). Financial Times, (Aanlyn). Beskikbaar: http://www.inet.co.za/ng2/ siteWide/content/access/1,2039,634276-5453-0,00.html (2000, Augustus 8).

Van Rensburg, C. \& Crous, F. (2000). Die verband tussen sekere persoonlikheidseienskappe en transformasionele leierskap. Tydskrif vir Bedryfsielkunde, 26(3), 39-46.

Walkden, J. (1998, September). Managing resources in technology driven enterprises: The call center conundrum, (Aanlyn). Beskikbaar: http://www.callentre.co.uk/now/ GENERAL/ managingres.htm (2001, Augustus 28).

Williams, G. (2000). When does the call centre bubble burst?, (Aanlyn). Beskikbaar: http://www.callcentre.co.uk/now/ GENERAL/Bubble.htm (2001, September 17). 